\title{
The Relationship of Arrogance Leadership, Job Commitment, and Job Satisfaction in Higher Educational Organisations in Sarawak
}

\author{
Jefferson Poh Thong Sim ${ }^{1}$, Ying-Leh Ling ${ }^{2 *}$ \\ ${ }^{1}$ School of Education, Languages and Communications, \\ 54, Jalan Sultan Ahmad Shah, Penang, 10050, MALAYSIA \\ ${ }^{2}$ Mathematics, Science and Computer Department, \\ Politeknik Kuching Sarawak, KM22, Jalan Matang, Kuching, Sarawak, 93050, MALAYSIA \\ *Corresponding Author
}

DOI: https://doi.org/10.30880/ojtp.2020.05.02.006

Received 24 April 2020; Accepted 5 August 2020; Available online 30 September 2020

\begin{abstract}
This is a study about the relationship of arrogance leadership, job commitment and job satisfaction in higher educational organisations in Sarawak. This study looked into whether the level of job commitment and job satisfaction in an organisation is highly related to the type of leadership style portrayed by leaders in higher educational organisations. It was implemented to further understand the correlational relationship between arrogance leadership (independent variable) and job commitment and job satisfaction (dependent variables). The research instrument, a questionnaire through an online platform - Google Form, was distributed from January till February 2020. The data were collected from one hundred and thirty respondents from twenty-one higher educational organisations in Sarawak. The data was analysed using the SPSS software. The findings of this study proved that although the level of arrogance leadership may be at the below average level or at its infancy stage, it is important to note that it exists in higher educational organisations which will significantly affect other variables like job commitment and job satisfaction. This is supported when the findings showed that the overall level of job commitment is also low. Lastly, the findings proved that there are significant relationships between arrogance leadership with job commitment and job satisfaction among the lecturers. Practically, this study is able to help higher educational organisation and its management to identify the level of arrogance leadership, job commitment and job satisfaction within its organisation. Theoretically, on the other hand, this study is unique as it focused on the Malaysian context.
\end{abstract}

Keywords: Arrogance leadership, arrogance, leadership, arrogant leader, educational leader, higher educational organisations

\section{Introduction}

Arrogant leaders are leaders acting without the consent of team members causing resistance and rebellion amongst their members (Haan, Britt, \& Weinstein, 2007; Toscano, Price, \& Scheepers, 2018). In short, a person who has a high sense of superiority is also inaccessible and usually unapproachable; he is viewed as arrogant (Toscano et al., 2018; Trumpeter, Watson, \& O'Leary, 2006). Hence, a person who has subordinates or a reporting line and possesses the characteristics of arrogance is considered an arrogant leader and arrogance leadership is demonstrated when someone in the organisation possesses a sense of superiority and exaggerated self-importance (Toscano et al., 2018). Arrogance may not be a leadership style, but it is a personality trait or attribute influencing the leadership style of the leader. Many scholars have identified the occurrence of this phenomenon among leaders across various fields and its impacts on individuals such as employees or followers (Johnson et al., 2010; Silverman, Johnson, McConnell, \& Carr, 2012; 
Toscano et al., 2018). Without a doubt, arrogance leadership when practised (without early detection and control) is believed to have impacts on individuals, individuals in organisation and the organisation as a whole. In this study, an arrogant leader is someone displaying or practising arrogance leadership in an organisation, specifically educational organisation. The relationship of arrogance leadership with job commitment and job satisfaction is a myth or a known fact that is happening in organisations which has been ignored by individuals? In order to answer this question, Hazriyanto and Ibrahim (2019) noted that through the enhancement of job satisfaction among lecturers, not only can work performance improved but also able to develop and cultivate job commitment. The behaviour or style of leadership portrayed by leader is deemed to have direct influence on the employees' job satisfaction, and subsequently their commitment (van den Berg \& Wilderom, 2004). To better understand the connection or relationship between these factors, Hazriyanto and Ibrahim (2019) outlined that job satisfaction can be both negative and positive perspectives of an individual linked with the job; the performance is the work outcome; and the management process is the leadership style of the leader. Hence, satisfaction is one factor that contributes toward enhancing the achievement of job performance, which will then lead to commitment. This study is unique in comparison with other studies, as it seeks to identify the level of arrogance leadership, job commitment and job satisfaction in educational organisations as well as the relationship between arrogance leadership, job commitment and job satisfaction.

\subsection{Research Objectives}

The research objectives of this study are:

- To identify the level of arrogance leadership in educational organisations.

- To identify the level of job commitment among the lecturers in educational organisations.

- To determine the significant relationship between arrogance leadership and job commitment.

- To identify the significant influence of arrogance leadership towards job satisfaction among the lecturers.

\section{Impact of arrogance leadership toward job commitment and job satisfaction}

Humans are sentient beings with emotions and are easily affected by others. An arrogant leader is able to push followers, both positively and negatively (Dykes \& Winn, 2019). This may result in being either valuable or toxic as it can drive individuals to exceed their potentials. This is useful in situation where an immediate change is required (Dykes \& Winn, 2019). Arrogance can be exhibited by all individuals within the organisation, regardless of their roles - as leaders or subordinates. It is like a vicious cycle occurring from the leader to the subordinates, subordinate to the leader or even between subordinates who like to claim seniority over peers. When a study was conducted in educational organisation on the students' arrogance level, male students were found to be more arrogant than female students (Haan et al., 2007). In contrast, there was no significant difference between traditional and non-traditional students (Haan et al., 2007). Hence, it is assumed that students feel equal with each other based on their study mode. However, Hamedoğlu (2019) investigated that the level of organizational narcissism, which resulted in arrogance, of private schools were higher amongst the students. Haan et al. (2007) implied that there were no significant differences of perceived arrogance on educators; on demographic variables like age, ethnicity, geography, and educational background. In contrast, a research study showed that socio-economic level and academic achievement is related linearly to individual's and organisation's narcissism (Hamedoğlu, 2019). Due to high academic requirements to be employed as lecturers, it can be predicted that leaders in educational organisations will tend to have arrogance attributes as they progress academically and in their career. Hence, it is no surprise that arrogant leaders will have impacts on individuals and their followers. In educational context (especially in the competitive environment of higher education), lecturers are required to take on more roles (other than learning and teaching) such as administrative and management tasks, it is no surprise that these so-called leaders will tend to act based on arrogance traits. van den Berg and Wilderom (2004) believed that positive leadership behaviour has significance influence to enhance employees' job satisfaction. Positive leadership behaviours such as the empowerment of employees through leadership roles and autonomy will enhance employee job performance and promoting better working environment within the organisations. This can only be achieved without the presence of arrogance in the organisations. Therefore, leaders in organisations should have enhanced leadership behaviour to increase employees' trust and motivation, which will then increase satisfaction and commitment (van den Berg \& Wilderom, 2004).

\subsection{Impact of arrogance leadership on individuals in organisation}

Organisations are formed by a group of individuals. The success of it relied heavily on teamwork and a good leadership. A good leadership style shown by leaders is the driving force for the direction of the any organisations. Toscano et al. (2018) believed that the levels of positive attitudes shown by followers and subordinates; team members, are highly dependent and determined by levels of humility exuded by the leader. Liborius (2017) further supported by stating that influencing characters such as integrity, humility and forgiveness are very crucial in determining good leadership. An environment lacked of humility and integrity amongst its team members can cause negative and unhealthy work culture (Oyer, 2015). It was noted that these attributes were rarely been studied under leadership research and still lacks empirical studies (Liborius, 2017; Toscano et al., 2018). Without a doubt, leaders can influence 
the flow and direction of the team in any organisation. Therefore, it is important for any organisation to redirect arrogant behaviour portrayed by its leaders (Silverman et al., 2012). Not excluded, educational organisations are operated by individuals and even though educators fear that they are being viewed as arrogant by students, it was found that students did not think of educators as arrogant (Haan et al., 2007). However, educators are reminded to be careful and understand the difference between being arrogance and confidence (Haan et al., 2007). Hence, educational organisations usually collect students' feedbacks at the end of every semester for the lecturers' self-reflection and continuous quality improvement on their learning and teaching practices. Lecturers are vital leaders of classrooms, and their leadership style can and will affect students' learning outcomes and graduate attributes. In order to avoid arrogance from cultivating, early detection is very crucial to avoid it from affecting individuals in the organisations. Silverman et al. (2012) recommended that it is achievable through the reinforcement of continuous development of leadership based on adequate job-related skills efficacy, healthy levels of humility amongst employees, and inculcating a learning-oriented environment. In today's day and age, every individual is capable and can be treated as leader. Thus, this approach allows educational organisations to identify and groom individuals as positive and impactful leaders within the organisations. As a high level of commitment shown by employees is able to enhance productivity, it was found that there is a positive relationship between development, training and job satisfaction at workplace (Hazriyanto \& Ibrahim, 2019). In relation, it was also found that there is a significant relationship between job satisfaction and organizational commitment with leadership style among university lecturers (Hazriyanto \& Ibrahim, 2019; Tatlah, Akhtar, \& Hashmi, 2019). Also, it seems that when given autonomy, teachers or employees tend to have higher satisfaction and commitment level (Mendoza, 2019; Saba, 2011; Tatlah et al., 2019).

\subsection{Implication of arrogance leadership on organisation}

Arrogance is believed to be one of the main causes of leaders' failure (Toscano et al., 2018). As leaders lead organisations, thus their failures will cause the organisations to fail as well. It is getting more apparent that arrogance has become a common trait in many organisations and cultivated as part of the organisational culture (Toscano et al., 2018; Hamedoğlu, 2019). As the workforce is getting more competitive and demanding, leaders have been known to use arrogance to intimidate followers to communicate and collaborate with each other within organisations (Toscano et al., 2018). This approach can fruit immediate results in the short term, but excessively, it will grow into a toxic organisational environment causing discomfort and dissatisfaction. Many scholars have studied the impact of leadership styles on employees based on factors like gender, age and race, however not many studies were done on arrogance leadership and its impact on job commitment and satisfaction, especially in educational organisations (Cansoy, 2019; Sharma, Aryan, Singh, \& Kaur, 2019; Trimmer, Dixon, \& Guenther, 2019). To expand the current literature, Trimmer et al. (2019) suggested that studies on the relationships between leadership style and job satisfaction should be conducted in different education settings. It was also mentioned that job satisfaction and leaders' leadership behaviours such as arrogance could be examined (Trimmer et al., 2019). In addition, it is predicted that individuals working in an organisation that consistently aim to be more superior than other organisations are likely to be arrogant (Hamedoğlu, 2019). Hence, showing that arrogance is contagious and can foster by individuals and within organisations. Lastly, arrogance leadership will affect the entire organisations.

\subsection{Job Commitment}

Commitment can be simply defined as the actions of each individual on work or at the workplace, which can be determined and observed through a sense of belonging and level of involvement portrayed toward the organization (Meyer et al., 1989; Tatlah et al., 2019). According to Meyer et al. (1989), it was deduced that other work-related behaviours (other than turnover) contribute significantly toward job commitment. Employees might not leave the job due to factors like salary and benefits, but they do not contribute wholeheartedly to the organisations. Loyalty and commitment are totally different variables. In other words, a person can be loyal but not committed. Therefore, leadership effectiveness must be measured through not only followers' loyalty but commitment as well (Deal, 1985). Other work-related behaviours such as arrogance leadership can cause employees to be reluctant and resistant to work at full capacity (Allen \& Meyer, 1993). Mendoza (2019) affirmed that for employees to be committed or have a higher level of job commitment, they must be able to identify with the organizations that they are working for and must be fully engaged or feel engaged in the daily operations. In other words, commitment is believed to be a desirable quality to inculcate amongst employees for an organization to strive successfully as well as maintaining economies of scales. As employees progressed professionally and personally in their career stage, their level of commitment may increase and decrease too from various factors (Allen \& Meyer, 1990a; Allen \& Meyer, 1990b). This may be resulted from being saturated at one job for too long or affected by leadership style of the leader. Without a doubt, the value of commitment toward the organization can be determined by the nature of that commitment (Meyer et al., 1989). Commitment can be divided into three categories; namely normative commitment, affective commitment, and continuance commitment, with each dimension being developed independently to wield the different effects on workrelated behaviour (Allen \& Meyer, 1993; Allen \& Meyer, 1990a; Allen \& Meyer, 1990b).

\subsubsection{Normative Commitment}


Normative commitment is looking at the perceived obligations of employees toward the organisation (Allen \& Meyer, 1993; Meyer et al., 1989). This means that employees who are normatively committed to the organisations are usually the ones who viewed their job as responsibilities or career rather than a task to accomplish or complete. According to Allen and Meyer (1993), this kind of feeling of obligation to remain with the organisation comes with age and seniority of the employees. It is believed that as employees grow older in terms of their age and the longer their years of service, the perceived obligation is higher as compared to younger and newer employees in the organisation (Jaros, 2007).

\subsubsection{Affective Commitment}

Affective commitment is looking at the emotional ties the employees have with the organisation (Allen \& Meyer, 1993; Meyer et al., 1989). Similar to normative commitment, their desire to remain with the organisation comes with their years of service and age as well (Allen \& Meyer, 1993). It can be said that the longer employees have served the organisation; they are more attached and value their association with the organisation (Meyer et al., 1989). This means that they are more likely to remain with the organisation as well as to work toward success of it. On the flip side, if employees lose the emotional bond they have with the organisation, they will choose to leave as they do not feel obligated or are not motivated by any reward.

\subsubsection{Continuance Commitment}

Human beings are attracted and motivated by rewards, both monetary and non-monetary. With that, the continuance commitment is looking at the perceived cost or risk the employees need to bear to leave the organisation (Allen \& Meyer, 1993; Meyer et al., 1989). If the costs (risk of losing the salary and benefits) to bear for leaving would be too high or unbearable, employees might choose to remain (Allen \& Meyer, 1993). As compared to affective commitment, this means that they solely choose to remain because they need to and not because they want to. Although choosing to remain and stay committed, employees might not strive to perform better or ever be satisfied with the organisation (Mendoza, 2019).

\subsection{Job Satisfaction}

Satisfaction is the state of feeling accomplished and appreciated, which is why job satisfaction has been treated as indicator affecting various organisational outputs such as performance, recognition and notably, job commitment (Ozdem \& Sezer, 2019; Uysal, 2019). By simply completing a task does not exactly constitute satisfaction, hence, job satisfaction has consistently been examined at individual and organisational level. According to Uysal (2019), the factors that are affecting satisfaction for individuals are socio-cultural environment, intelligence, personality, occupational status and work, level of education, marital status, gender and age. In addition, it was found that the styles of supervision and management portrayed by leaders could affect job satisfaction at the organisational level (Ozdem \& Sezer, 2019; Uysal, 2019). In the educational context, Saba (2011) noted that the level of satisfaction is higher amongst teachers who have been in the profession for more than 21 years. So, does this mean that longer years of service will increase job satisfaction? Uysal (2019) supported this claim by stating that when satisfaction level is low, employees will start looking for new job opportunities, which can negatively affect commitment. Apart from the fact that it is the desire and motivation of employees to be and remain satisfied with their jobs, it is also very much the responsibilities of the managers or leaders of the organisations to increase job satisfaction through managerial strategies and leadership style (Uysal, 2019). Leaders who are arrogant and unapproachable can cause dissatisfaction amongst followers (Torlak \& Kuzey, 2019). In a study conducted by Saba (2011), further proved that the relationships with superiors and colleagues are determining factor of satisfaction for the teachers. This clearly showed that humility and teamwork is very crucial for leaders to practise when ensuring followers are satisfied at the workplace. This leaves no room for leaders to be arrogant. Saba (2011) also investigated that most teachers felt content (reported high in satisfaction) with the nature of the job and its accompanying workload as long as there is a sense of accomplishment and fulfilment acknowledged by their superiors. The heavy workload is not the determining factor of stress and dissatisfaction but rather the type of leadership style portrayed by their leaders such as being arrogant and not recognising and appreciating individuals' hard work. In the long run, under the guidance of negative leadership, job satisfaction will keep on reducing until diminished (Uysal, 2019). Without a doubt, dissatisfaction caused by arrogance leadership will result in employees' burnout, leaving negative consequences happening in the organisations (Borden, 2017).

\section{Methods}

This study was implemented to understand the correlational relationship of arrogance leadership and job commitment and job satisfaction in higher educational organisations. It is believed to be able to provide concrete and accurate descriptions to an identified problem or situation by making assumptions of the way things are and provoke actions (De Vaus, 2001; Fraenkel, Wallen \& Hyun, 2011). Therefore, this study would be able to confirm the significant relationship of arrogance leadership with job commitment and job satisfaction in higher educational institutions 


\subsection{Population, Sampling and Sample}

The population of this study was lecturers (involved in learning and teaching) at both public and private higher educational organisations such as universities, university colleges, and colleges. Hence, the sampling frame was lecturers working at both public and private universities, university colleges and colleges. Due to the vast geographical and widely scattered locations of educational organisations in Sarawak, this study applied the random sampling method. According to the statistics of higher educational organisations provided by the Ministry of Education, there are 29 higher educational organisations in the state of Sarawak; namely one public university, one private university, one university college, two foreign branch universities and 24 colleges (Senarai Daftar IPTS, 2019, November 30). As Kuching is the capital city of Sarawak and with the most numbers (a total of 16) of higher educational organisations, this location was chosen as one of the two selected locations. Another location selected, Sibu with a total of five higher educational organisations, is the closest division to Kuching, which are both the southern part of Sarawak. The other two major divisions - Bintulu and Miri are located in the northern part of Sarawak, with a combined total of eight higher educational organisations only. Out of the total 29 higher educational organisations located in Sarawak, 21 (72 percent) are located in Kuching and Sibu (southern part of Sarawak). Hence, both Kuching and Sibu were chosen as the location of research to target the sample. By dividing the population into separate groups according to the locations provided a better focus during data collection (Kemper, Stringfield, \& Teddlie, 2003). The random sampling method involved fewer resources as the need to focus on multiple locations was reduced (Lohr, 2019). This made the study more feasible and able to focus on getting more respondents in a specific location. By focusing on specific locations, the random sampling method was also able to reduce the variability of this study, which would result in a more accurate reflection of the population (Lohr, 2019). Initially, there were 233 online survey links emailed/ distributed to lecturers from 21 higher educational organisations in Kuching and Sibu. During the closure of the online survey (one-month period), a total of 130 responses were successfully collected. Only 19 out of the 21 higher educational organisations have at least one respondent. This data collection achieved an almost 57 percent response rate.

Table 1 - Statistics of higher educational organisations in Sarawak

\begin{tabular}{|c|c|c|c|c|c|c|}
\hline Location & $\begin{array}{c}\text { Public } \\
\text { University }\end{array}$ & $\begin{array}{c}\text { Private } \\
\text { University }\end{array}$ & $\begin{array}{l}\text { University } \\
\text { College }\end{array}$ & $\begin{array}{c}\text { Foreign Branch } \\
\text { University }\end{array}$ & College & Total \\
\hline Kuching & 1 & 1 & - & 1 & 13 & 16 \\
\hline Sibu & - & - & 1 & - & 4 & 5 \\
\hline Miri & - & - & - & 1 & 5 & 6 \\
\hline Bintulu & - & - & - & - & 2 & 2 \\
\hline Total & 1 & 1 & 1 & 2 & 24 & 29 \\
\hline
\end{tabular}

\subsection{Research Instrument}

This study utilised a questionnaire to obtain the necessary data through an online platform - Google Form. The questionnaire was divided into four sections; section one - respondents' profile, section two - arrogance leadership; section three - job commitment; and section four - job satisfaction. Table 2 outlined the research instrument items.

Table 2 - Research instrument

\begin{tabular}{ccll}
\hline \multicolumn{1}{c}{ Item } & $\begin{array}{c}\text { Total } \\
\text { Items }\end{array}$ & \multicolumn{1}{c}{ Sources } \\
\hline Section One - Respondents' Profile & 5 & - \\
Section Two - Arrogance Leadership & 26 & Workplace Arrogance Scale (Johnson et al., 2010) \\
Section Three - Job Commitment & 24 & Commitment Scale Items (Allen \&Meyer, 1990a; Allen \& Meyer, \\
Section Four - Job Satisfaction & 20 & Job Satisfaction Scale (Weiss et al., 1967) \\
\hline Total & 75 & \\
\hline
\end{tabular}

The Workplace Arrogance Scale has 26 items scale to measure arrogance at workplace with a five-point Likertscale from 1 (strongly disagree) to 5 (strongly agree) (Johnson et al., 2010; Silverman et al., 2012). All the three subscales of the job commitment scale were using five-point Likert-scale from 1 (strongly disagree) to 5 (strongly agree). The job satisfaction scale was also using the five-point Likert-scale from 1 (very dissatisfied) to 5 (very dissatisfied). Although past studies by scholars who adopted similar scales have proven the validity of their in struments using the five-point Likert-scale (Allen \& Meyer, 1993; Johnson et al., 2010; Weiss et al., 1967), this study applied the six-point Likert-scale. The six-point Likert-scale is considered a force scale whereby respondents are required to choose whether they agree or disagree, instead of choosing to remain neutral. In a study conducted by Chang (1994), the six-point Likert-scale resulted in higher validity and reliability. In addition, Chomeya (2010) posited that the sixpoint Likert-scale (instead of the five-point Likert-scale) would produce more variation, have higher chance to produce significance as well as reliability. Therefore, the instrument applied the six-point Likert-scale. This approach has been 
tested reliable during the pilot test and implemented for the final data collection. For data collection, this study utilised the online survey questionnaire method through the Google Form online platform and via email blasting. Nulty (2008) supported that web-based or technology-supported or online questionnaires are proven to have faster and higher response rates as compared to the traditional paper-based questionnaires. In relation, Sheehan (2001) also claimed that using email as the medium to distribute the questionnaire is cost efficient (eliminates printing cost), time saving (able to reach wider and more audience) and convenience to respondents (complete at own time and place). Hence, there were no pressure on the respondents (to simply completing the survey) and able to provide good quality responses (Granello \& Wheaton, 2004). Prior to email blasting, research ethical clearance and permission to access lecturers' email addresses are obtained (Granello \& Wheaton, 2004; Minnaar \& Heystek, 2013). The final data were gathered for four weeks in January and February 2020. It was during the Chinese New Year period as well as semester break for some higher educational organisations, hence slow and low response rates. The response rate had to be monitored and reminder emails were sent several times to remind respondents to complete the survey. In the end, with the cooperation of respondents and the advantage of using an online survey, respondents were able to complete the survey through their mobile phones even during the holiday season.

\subsection{Pilot Test}

A pilot test was conducted from 1 January till 10 January 2020, to validate the effectiveness of the instrument questionnaire (Fraenkel, et al., 2011; Neuman, 2011). It was also to test the questions' ability to provide the intended responses to answer the research objectives. The questionnaires were sent to lecturers of a private university in Sarawak. Thirty respondents were involved in the pilot study but not included in the final sample. A reliability analysis was conducted to determine the internal consistency of the research scales (Coakes \& Steed, 2009; Green \& Salkind, 2016). For this pilot study, the Cronbach's alpha was tested and achieved the value of .84. Hair, Black, Babin, Anderson, and Tatham (1998) stated that the Cronbach's alpha values between .60 and .70 are acceptable. Hence, there were no modifications done to the instrument based on pilot study results.

\section{Data Analysis}

All data collected are interpreted quantitatively through the Statistical Package for the Social Science (SPSS) (version 26.0) software (Green \& Salkind, 2016). The first step was running the descriptive analysis to provide a brief overview of the sample distribution and variables involved in this study (Coakes \& Steed, 2009). Next, running the frequencies function to provide the respondents' demographic characteristics (Coakes \& Steed, 2009; Green \& Salkind, 2016). The second step was to run the mean and standard deviation functions to describe the variables of this study (Coakes \& Steed, 2009). Both the independent and dependent variables were analysed using descriptive statistics to obtain the mean scores and standard deviation. Correlation analysis determined the direction and intensity of the relationship between the independent and dependent variables. The correlation coefficient (r), a bivariate analysis, was to measure the strength of the relationship between two variables (Sekaran \& Bougie, 2010; Green \& Salkind, 2016). For this study, the Pearson's correlation coefficient was used. As there were one independent variable and one dependent variable in each hypothesis, the simple linear regression analysis was used to test the hypotheses (Hair et al., 1998). It was used to examine the relationship between the independent and dependent variables. In contrast with correlation analysis, the simple linear regression analysis was used to predict the value of the dependent variables (Coakes \& Steed, 2009).

Table 3 - Data analysis

\begin{tabular}{|c|c|}
\hline Objectives & Type of Analysis \\
\hline $\begin{array}{l}\text { 1. To identify the level of arrogance leadership in } \\
\text { educational organisations. }\end{array}$ & $\begin{array}{c}\text { Frequency, percentage, mean and standard } \\
\text { deviation }\end{array}$ \\
\hline $\begin{array}{l}\text { 2. To identify the level of job commitment among the } \\
\text { lecturers in educational organisations. }\end{array}$ & $\begin{array}{c}\text { Frequency, percentage, mean and standard } \\
\text { deviation }\end{array}$ \\
\hline $\begin{array}{l}\text { 3. To determine the significant relationship between } \\
\text { arrogance leadership and job commitment. }\end{array}$ & Pearson Correlation \\
\hline $\begin{array}{l}\text { 4. To identify the significant influence of arrogance } \\
\text { leadership towards job satisfaction among the lecturers. }\end{array}$ & Simple Linear Regression \\
\hline
\end{tabular}

\section{Results and Discussions}

Out of the 130 responses received, there were no spoilt responses - no missing values. Therefore, the total usable data was 100 percent. Besides, all respondents are lecturers or somewhat involved in learning and teaching roles, hence, did not terminate the survey in section one. Therefore, all the 130 respondents were included for data analysis. The data collected were immediately coded and transferred to SPSS for processing. The transferred data were checked and reverse coded according to the negatively structured questions. To ensure the reliability, the Cronbach's Alpha test was run and achieved the .71 value. This showed the consistency obtained during the pilot study whereby the reliability coefficient value was at .84, both at the acceptable range (Hair et al., 1998). 


\subsection{Demographics of Respondents}

All 130 respondents were in-service lecturers at higher educational organisations in Kuching and Sibu; 60 respondents were from University or University College and 70 respondents were from College. All respondents, in their current role, were reporting to at least a superior or supervisor, except for one respondent who indicated not reporting to a superior. Out of the 130 respondents, only 28 of them have subordinates reporting to them. The number of respondents on the years of service were distributed quite evenly over the three categories; less than five years -44 respondents, five to nine years -46 respondents, and ten years and above -40 respondents.

\subsection{Level of Arrogance Leadership}

To answer the first research objective, the level of arrogance leadership was determined based on the median, mean, quartile and percentile of the sample of this study. From this calculation, the mean range of $1.00-3.88$ was considered low, 3.89 - 4.18 was below average, 4.19 - 4.53 was above average and $4.54-6.00$ was high. As there were 26 items in the arrogance leadership scale as developed by Johnson et al. (2010), this discussion looked at the top five highest and lowest mean of the items. Out of the top five highest mean, three items scored the high level of arrogance leadership; Item 9 "Exhibits different behaviours with subordinates than with supervisors" $(\mathrm{M}=4.94, \mathrm{SD}=1.498)$, Item 22 "Does not mind menial tasks" $(\mathrm{M}=4.80, \mathrm{SD}=1.284)$, and Item 1 "Believes that s/he knows better than everyone else in any given situation" $(\mathrm{M}=4.59, \mathrm{SD}=1.139)$. This was consistent with the studies by Toscano et al. (2018) and Trumpeter et al. (2006) whereby arrogance leadership happened when a leader who had a high sense of superiority was also inaccessible and usually unapproachable. The remaining two items of the top five highest mean were located in the above average level of arrogance leadership; Item 2 "Makes decisions that impact others without listening to their input" $(\mathrm{M}=4.50, \mathrm{SD}=1.176)$ and Item 14 "Takes responsibility for his/ her own mistakes" $(\mathrm{M}=4.48$, $\mathrm{SD}=1.221$ ). Items 14 and 22 were negative statements in the instrument, hence respondents were perceiving that their superiors "don't take responsibility for own mistakes" and "mind doing menial tasks", respectively. This finding was definitely echoing what Toscano et al. (2018) has posited earlier; arrogant leaders were believed to have an impact on followers and subordinates on variables such as engagement, cohesiveness, collaboration and consensual decision making. All of the top five lowest means were considered low for having a mean score of below 3.88. The five items of the low level of arrogance leadership were Item 5 "Belittles his/ her employees publicly" $(\mathrm{M}=2.93, \mathrm{SD}=1.410)$, Item 8 "Shoots down other people's ideas in publics" $(\mathrm{M}=2.95, \mathrm{SD}=1.354)$, Item 3 "Uses non-verbal behaviours like glaring or staring to make people uncomfortable" $(\mathrm{M}=3.22$, $\mathrm{SD}=1.290)$, Item 4 "Criticise others" $(\mathrm{M}=3.51, \mathrm{SD}=$ 1.354), and Item 7 "Discredits others' ideas during meetings and often makes those individuals look bad" ( $\mathrm{M}=3.53$, $\mathrm{SD}=1.215$ ). All 26 items had a standard deviation value of less than 1.500 , which was considered low and proved that the responses to the items are close to the average or mean of the data set. This also showed that respondents are choosing almost all similar responses. Only one item had a standard deviation value of less than 1.000; Item 25 "Does not see him/herself as being too important for some tasks" $(\mathrm{M}=4.32, \mathrm{SD}=.989)$. In contrast, Toscano et al. (2018) in their study found that arrogant leaders were causing grievances to followers and subordinates by creating an environment of intimidation. However, the finding of this study showed that respondents were saying that their superiors were not humiliating them publicly, did not criticise and also not using non-verbal behaviours to create awkward situations. The overall arrogance level scored the below average level $(\mathrm{M}=4.09, \mathrm{SD}=.858)$, and it was identified at an acceptable level. This may be due to workplace bureaucracy, whereby respondents chose to keep silent when faced with arrogance leadership in an environment of intimidation (Toscano et al., 2018). During the data collection stage, there were lecturers from several higher educational organisations who were reluctant to participate in the survey due to fear of their responses being identifiable. In relation, arrogance was demonstrated by disparaging others and often regarded as a negative attribute in any organisation but widely and subconsciously practised by many leaders (Silverman et al., 2012). In short, a person with a high sense of superiority was viewed as arrogant (Toscano et al., 2018; Trumpeter et al., 2006). This was fully supported by the findings whereby the top three highest scored means.

The respondents agreed that their superiors acted differently when dealing with their supervisors, minded doing menial tasks and believed that they were better than anyone else in a given situation. This showed that the respondents perceived that their superiors were not only unapproachable but have a high sense of superiority above subordinates. They perceived that their superiors were demonstrating the traits of arrogance. Besides, the presence of arrogance can also be identified when arrogance leadership is demonstrated by someone in the organisation who possessed a sense of superiority, exaggerated self-importance and acted without the consent of team members causing resistance and rebellion amongst their members (Haan et al., 2007; Toscano et al., 2018). These statements were also supported by the findings of this study whereby Item 2 "Makes decisions that impact others without listening to their input" $(\mathrm{M}=4.50$, $\mathrm{SD}=1.176)$ and Item 14 "Takes responsibility for his/ her own mistakes" $(\mathrm{M}=4.48, \mathrm{SD}=1.221)$ also topped the highest scored means. However, it can be noticed that the respondents were not rebellious yet toward their superiors as all of the top five lowest means are identified as low. This showed that the respondents were still able to be objective when responding to the statements of the scale. The respondents were not bias or resistant as they were still able to agree that their superiors did not humiliate them in public or during meetings. Nevertheless, it was cautioned by Toscano et al. (2018) that the existence of arrogance leadership was undesirable as it leads to ineffective leadership and in the long run may cause grievances to subordinates. As all respondents stated that they were reporting to at least a 
superior or supervisor, except for one respondent, it can be claimed that the arrogance leadership existed and was consistent across the higher educational organisations. In relation, the existence or occurrence of arrogance leadership was also consistent with other studies and imposing impacts on individuals such as employees or followers (Johnson et al., 2010; Silverman et al., 2012; Toscano et al., 2018). For this study, it was concluded that even though the level of arrogance may be at the below average level, it is important to note that the findings proved that its existence in higher educational organisations. And, without early detection and control, arrogance leadership is believed to have negative impacts on the lecturers as individuals, amongst the lecturers in higher educational organisations and the higher educational organisations as a whole (Johnson et al., 2010; Silverman et al., 2012; Toscano et al., 2018).

\subsection{Level of Job Commitment}

To answer the second research objective, the level of job commitment was determined lated based on the median, mean, quartile and percentile of the sample of this study. From this calculation, the mean range of $1.00-3.27$ was considered low, 3.28 - 3.45 was below average, 3.46 - 3.62 was above average, and 3.63 - 6.00 was high. The job commitment as dependent variable consisted of three sub-scales - a normative commitment which was based on perceived obligation toward the organisation; an affective commitment which was based on the emotional ties developed by employees through the positive working environment or workplace; and a continuance commitment which was based on the perceived cost (both economically and socially) of leaving or quitting from the organisation (Jaros, 2007). Hence, the job commitment level was discussed based on the three sub-scales.

\subsubsection{Normative Commitment}

The Normative Commitment Scale was an eight-item scale enhanced by Meyer and Allen from their work in 1984 (Allen \& Meyer, 1993; Jaros 2007). Out of the eight items, only two items were in the high-level range; Item 1 "I think that people these days move from company to company too often." $(\mathrm{M}=4.18, \mathrm{SD}=1.002)$ and Item 4 "One of the major reasons I continue to work in this organisation is that I believe loyalty is important and therefore feel a sense of moral obligation to remain." $(\mathrm{M}=3.70, \mathrm{SD}=1.001)$. Only one item was at the above average level, Item 6 "I was taught to believe in the value of remaining loyal to one organisation." $(\mathrm{M}=3.49, \mathrm{SD}=.856)$. Based on the findings, the overall normative commitment level was low $(\mathrm{M}=3.12, \mathrm{SD}=.503)$. The rest of the five items were in the low-level range, with Item 5 "If I got another offer for a better job elsewhere I would not feel it was right to leave my organisation." $(\mathrm{M}=2.52, \mathrm{SD}=1.115)$ scoring the lowest. This finding proved the consistency of the responses with the definition of normative commitment, whereby it was looking at the perceived obligations of employees toward the organisation (Allen \& Meyer, 1993; Meyer et al., 1989). However, as stated earlier that although 66 percent of the respondents have been working in their current higher educational organisations for more than five years, the normative commitment is still low. As opposed to the claims of Jaros (2007), that as employees grew older in terms of their age and the longer their years of service, the perceived obligation should be higher in the higher educational organisations.

\subsubsection{Affective Commitment}

The Affective Commitment Scale was an eight-item scale developed by Meyer and Allen in 1984 (Allen \& Meyer, 1993; Jaros, 2007). All eight items in the affective commitment scale were in the low-level range. The lowest was Item 1 "I would be very happy to spend the rest of my career with this organisation." $(\mathrm{M}=2.38, \mathrm{SD}=1.129)$. This proved that affective commitment was low amongst the respondents. In contrast, Item 4 "I think that I could easily become as attached to another organisation as I am to this one" $(\mathrm{M}=3.27, \mathrm{SD}=.861)$ was at the end range of the low level nearing the above average level. This was a negative statement, therefore it showed that respondents even though did not wish to remain committed to the current organisation might not be easily attached to another or new organisation.

This was consistent with the definition of affective commitment whereby it was looking at the emotional ties the employees have with the organisation (Allen \& Meyer, 1993; Meyer et al., 1989). Based on the findings, the overall affective commitment was also low $(\mathrm{M}=2.86, \mathrm{SD}=.583)$ proving that affective commitment level was low amongst the respondents. Although Meyer et al. (1989) claimed that the longer employees have served the organisation they were more attached and valued their association with the organisation, but the findings of this study proved otherwise. Similar to normative commitment, although 66 percent of the respondents had been working in their current higher educational organisations for more than five years, the affective commitment was significantly low.

\subsubsection{Continuance Commitment}

The Continuance Commitment Scale was an eight-item scale developed by Meyer and Allen in 1984 (Allen \& Meyer, 1993; Jaros, 2007). In direct opposite to affective commitment, all eight items of the continuance commitment scale scored the high level of having the mean of 3.63 and above. The highest was Item 7 "One of the few serious consequences of leaving this organisation would be the scarcity of available alternatives." $(\mathrm{M}=4.72, \mathrm{SD}=1.221)$ and the second highest was Item 6 "I feel that I have very few options to consider leaving this organisation." $(\mathrm{M}=4.62$, SD $=1.171$ ). This somewhat showed that respondents had been staying committed because they perceived that there was a lack of opportunities outside their current organisations. They were willing to stay and put up with the arrogance 
leadership shown by the superiors. Without a doubt, this was consistent with the definition of continuance commitment whereby it was looking at the perceived cost (both economically and socially) or risk the employees needed to bear to leave the organisation (Allen \& Meyer, 1993; Meyer et al., 1989). However, choosing to remain and stay committed did not mean that employees strived to perform better or ever be satisfied with the organisation (Mendoza, 2019). Based on the findings, the overall continuance commitment was high $(M=4.35, \mathrm{SD}=.767)$. A person can be loyal but not committed, as they perceived that there was lack of opportunities outside their current organisations and if the costs to bear for leaving would be too high or unbearable (Allen \& Meyer, 1993; Mendoza, 2019). This meant that they solely chose to remain because they needed to and not because they wanted to.

Out of the 130 respondents, 86 respondents or 66 percent of the sample were in the long service category or considered loyal. However, based on the findings, the overall job commitment level was low $(\mathrm{M}=3.44, \mathrm{SD}=.368)$. This further proved that loyalty and commitment were different variables, and other work-related behaviours (other than turnover) contributed significantly toward job commitment (Meyer et al., 1989). For this study, in answering the second research objective, it can be concluded that the overall level of job commitment, after considering all three subscales, was still low. This was in support with the claims of Meyer et al. (1989) and Tatlah et al. (2019), commitment was determined and observed through a sense of belonging and level of involvement portrayed toward the organization, rather than the actions of staying or remaining loyal to the organisations.

\subsection{Correlation between Arrogance Leadership and Job Commitment}

Pearson's correlation analysis was looking at the coefficient to measure the direction and most importantly, the strength of the linear relationship between the independent and dependent variables (Bolboaca \& Jäntschi, 2006). The Pearson's correlation coefficient values from -1 to +1 ; a value of +1 showed that the variables are perfectly linear related by an increasing relationship, a value of -1 showed that the variables are perfectly linear related by a decreasing relationship, and a value of 0 showed that the variables are not linearly related by each other (Hair et al., 1998). From the results, arrogance leadership had significant negative relationship with normative commitment $(r=-.185, p<.05)$. This proved that the higher the arrogance level, the lower the normative commitment level. Likewise, arrogance leadership also had a significant negative relationship with affective commitment $(r=-.680, p<.01)$, proving that the higher the arrogance level, the lower the affective commitment level. As compared to both normative and affective commitment, arrogance leadership had a significant positive relationship with continuance commitment $(r=.350, p<$ $.01)$. This showed that when the level of arrogance increases, the level of continuance commitment increases as well. The continuance commitment was slightly different from the other two commitments because human beings are attracted and motivated by rewards, both monetary and non-monetary, and the fear of losing it is much greater than obligation and emotional ties towards the organisations (Allen \& Meyer, 1993; Meyer et al., 1989). This was also consistent with what Borden (2017) posited, arrogance leadership may cause burnout but employees will remain "committed" to the organisations due to fear of not receiving the same rewards in other organisations. Arrogance leadership can push followers, both positively and negatively, and can cause employees to be reluctant and resistant to work at full capacity (Allen \& Meyer, 1993; Dykes \& Winn, 2019). Therefore, leadership effectiveness must be measured through not only followers' loyalty but commitment as well (Deal, 1985). Without a doubt, leaders or superiors in the higher educational organisations must be able to exude confidence and empathy in leading their subordinates so that they remain committed for the right reasons. According to Oyer (2015), an organisation lacking humility, empathy, and integrity amongst its team members can cause negative and unhealthy work culture, which will then lead to a low commitment level. This was especially notable when the respondents stated that their superiors thought highly of themselves, minded doing menial tasks, exhibited different behaviours in front of others and showed lack of humility and empathy. Besides, Toscano et al. (2018) posited that the levels of positive attitudes that can be shown by followers and subordinates were highly dependent and determined by levels of humility exuded by the leader. The superiors were the main driving force behind the level of job commitment. However, leaders in higher educational organisations were to be constantly reminded to be careful and understand the difference between being arrogant and confident (Haan et al., 2007). For this study, in answering the third research objective, it can be concluded that the findings showed that there was a significant relationship between arrogance leadership and job commitment.

\subsection{Influence of Arrogance Leadership on Job Satisfaction}

The $R^{2}$ value, also known as the coefficient of determination provided information about the proportion of variation in the dependent variable being associated with the variation in the independent variable (Bolboaca $\&$ Jäntschi, 2006). For this study, The $R^{2}$ value indicated that arrogance leadership could explain 47.9 percent of the variance for job satisfaction. The $F$-ratio $(F=111.78, p<.10)$ proved that the $F$-change value was significant and the model was a good fit (Hair et al., 1998). Therefore, this showed that arrogance leadership is a good indicator in predicting job satisfaction. Further supporting the hypothesis that there was significant influence of arrogance leadership towards job satisfaction among the lecturers, the Durbin Watson value of 1.02 showed that there was positive autocorrelation between arrogance leadership and job satisfaction. The standardised coefficients $(\beta=-.692, p<$ 
.10) also proved that arrogance leadership was a significant predictor of job satisfaction. This simply meant that the higher the arrogance level the less satisfied the lecturers were. Hence, the findings showed that there was a significant influence of arrogance leadership towards job satisfaction among the lecturers. Satisfaction is the state of feeling accomplished and appreciated, which is why job satisfaction was considered to be able to affect various organisational outputs such as performance, recognition as well as job commitment (Ozdem \& Sezer, 2019; Uysal, 2019). On the other hand, the factors that were affecting satisfaction were working environment and conditions, colleagues, promotion opportunities, salaries, and benefits, communication, participation in decisions, sense of security, quality of work and styles of supervision and management portrayed by leaders (Ozdem \& Sezer, 2019; Uysal, 2019). Therefore, solidifying that arrogance leadership could be a good indicator in predicting job satisfaction (van den Berg \& Wilderom, 2004). In the educational context, it was noted that the level of satisfaction was higher amongst teachers who had been in the profession for longer time, as when satisfaction level was low, they would start looking for new job opportunities, which could negatively affect job commitment (Saba, 2011; Uysal, 2019). However, as stated earlier that although 66 percent of the respondents had been working in their current higher educational organisations for more than five years, the job satisfaction level was considered significantly low. Thus, proved that satisfaction and commitment had some sort of relationship to arrogance leadership. Apart from the fact that it was the desire and motivation of employees to remain satisfied with their jobs, it was also very much the responsibility of the managers or leaders of the organisations to increase job satisfaction through managerial strategies and leadership style (Uysal, 2019). Therefore, leaders in higher educational organisations should have enhanced leadership behaviour to increase the lecturers' trust and motivation, which will then increase satisfaction and commitment (van den Berg \& Wilderom, 2004). In relation, it also believed that when given autonomy, lecturers would have higher satisfaction and commitment level (Mendoza, 2019; Saba, 2011; Tatlah et al., 2019). In a study conducted by Saba (2011), further proved that the relationships with superiors and colleagues were determining factor of satisfaction for the teachers, it was found that $83 \%$ of the teachers involved in the study were satisfied because their superiors and colleagues were cooperative and provided sufficient support. Hence, the findings of this study were consistent with past studies by noting that arrogance leadership was a good indicator in predicting job satisfaction. This clearly showed that humility and teamwork were very crucial for leaders to practise when ensuring followers were satisfied at the workplace, leaving no room for leaders to be arrogant. It is also believed that leadership effectiveness would increase job satisfaction that would then lead to educational organisation effectiveness (Parker, 2015). For this study, in answering the fourth research objective, it can be concluded that the findings showed that there was a significant influence of arrogance leadership toward job satisfaction among the lecturers.

\subsection{Limitations of the Study and Future Research}

Like any other studies, this study was not excluded from having limitations. Firstly, as this study was focused in Sarawak, Malaysia, there were not many higher educational organisations included. It was believed that more educational organisations could be included to represent both public and private higher educational organisations in Malaysia. Next, as arrogance leadership can be practiced throughout an organisation, this study could have also included administrative staff or support staff working within the higher educational organisations. They contribute an equal amount of works and are also reporting to the same leader as the lecturers. Hence, future research can include both academic and administrative staff as the sample. Lastly, the period of the data collection was from 12 January 2020 till 12 February 2020. Due to the Chinese New Year period and also semester break for some higher educational organisations, the initial response was very low. Follow-ups through emails and phone calls were required to remind the potential respondents on the timeline to complete the survey. Hence, future research can consider doing the data collection in stages based on semester breaks of the higher educational organisations. As public and private higher educational organisations have different benefits, remuneration packages and job stability (Saba, 2011), future research can consider doing the comparison of the relationship of arrogance leadership with job commitment and job satisfaction between public and private higher educational organisations. When studied, satisfaction levels were higher in public educational organisations as compared to private ones; quoting that there is less bureaucracy with only one reporting head who does not intervene in the daily operations of teachers (Saba, 2011). It was noted by past studies that the desire to remain with the organisation comes with the years of service and age as well (Allen \& Meyer, 1993). Hence, future research can look at these two variables by comparing the years of service and age on the relationship of arrogance leadership with job commitment and job satisfaction. Not only that, Hamedoğlu (2019) also noted that other variables such as gender, position, academic qualifications and income may have an impact on arrogance leadership; the higher the academic qualification, the higher the arrogance. Therefore, future research can consider studying the impact of socio-economic variables on arrogance leadership. There were pieces of evidence of past studies proving that job commitment predicts job satisfaction (Mendoza, 2019). In theory, Uysal (2019) also posited that job satisfaction was regarded as the main element of job commitment. Hence, future research can consider studying the relationship or influence of job commitment and job satisfaction. 


\subsection{Managerial Implications and Conclusion}

Practically, this study helped higher educational organisation and its management to identify the level of arrogance leadership, job commitment and job satisfaction within its organisation. As arrogance is a type of changeable behaviour motivated by negative beliefs (Johnson et al., 2010), this study also allowed the higher educational organisation and its management to influence and increase job commitment and satisfaction level through leadership style. Without a doubt, being able to identify and limit arrogance at an early stage, effective leadership and productive social interaction amongst employees can be achieved by organisations (Silverman et al., 2012). Theoretically, this study was unique it focused on the Malaysian context. Besides, there were a lot of studies on leadership but not many are on arrogance leadership, especially in Malaysia. As to conclude, the findings of this study proved that although the level of arrogance leadership may be at the below average level or at its infancy stage, it is important to note that that it exists in higher educational organisations which will significantly affect other variables like job commitment and job satisfaction. This was supported when the findings showed that the overall level of job commitment was low. Lastly, the findings proved that there were significant relationships between arrogance leadership with job commitment and job satisfaction among the lecturers.

\section{Acknowledgement}

We are thankful to all quarters who have contributed to the research.

\section{Appendix A - Descriptive statistics of arrogance leadership}

Descriptive statistics of arrogance leadership ( $N=130)$

\begin{tabular}{|c|c|c|c|c|c|c|c|c|c|}
\hline \multirow{2}{*}{\multicolumn{2}{|c|}{ Items }} & \multicolumn{6}{|c|}{ Likert Scale } & \multirow[b]{2}{*}{ Mean } & \multirow[b]{2}{*}{ SD } \\
\hline & & 1 & 2 & 3 & 4 & 5 & 6 & & \\
\hline \multirow[t]{2}{*}{1} & Believes that s/he knows better than everyone & 3 & 10 & 4 & 19 & 78 & 16 & \multirow{2}{*}{4.59} & \multirow{2}{*}{1.139} \\
\hline & else in any given situation & 2.3 & 7.7 & 3.1 & 14.6 & 60 & 12.3 & & \\
\hline \multirow[t]{2}{*}{2} & Makes decisions that impact others without & 4 & 8 & 7 & 29 & 64 & 18 & \multirow{2}{*}{4.50} & \multirow{2}{*}{1.176} \\
\hline & listening to their input & 3.1 & 6.2 & 5.4 & 22.3 & 49.2 & 13.8 & & \\
\hline \multirow[t]{2}{*}{3} & Uses non-verbal behaviours like glaring or & 12 & 27 & 42 & 20 & 27 & 2 & \multirow{2}{*}{3.22} & \multirow{2}{*}{1.290} \\
\hline & staring to make people uncomfortable & 9.2 & 20.8 & 32.3 & 15.4 & 20.8 & 1.5 & & \\
\hline \multirow[t]{2}{*}{4} & Criticizes others & 13 & 16 & 34 & 32 & 29 & 6 & \multirow{2}{*}{3.51} & \multirow{2}{*}{1.354} \\
\hline & & 10 & 12.3 & 26.2 & 24.6 & 22.3 & 4.6 & & \\
\hline \multirow[t]{2}{*}{5} & Belittles his/her employees publicly & 26 & 25 & 38 & 17 & 21 & 3 & \multirow{2}{*}{2.93} & \multirow{2}{*}{1.410} \\
\hline & & 20 & 19.2 & 29.2 & 13.1 & 16.2 & 2.3 & & \\
\hline \multirow[t]{2}{*}{6} & Asserts authority in situations when s/he does & 10 & 5 & 10 & 38 & 56 & 11 & \multirow{2}{*}{4.22} & \multirow{2}{*}{1.288} \\
\hline & not have the required information & 7.7 & 3.8 & 7.7 & 29.2 & 43.1 & 8.5 & & \\
\hline \multirow[t]{2}{*}{7} & Discredits others' ideas during meetings and & 14 & 8 & 30 & 53 & 23 & 2 & \multirow{2}{*}{3.53} & \\
\hline & often makes those individuals look bad & 10.8 & 6.2 & 23.1 & 40.8 & 17.7 & 1.5 & & 1.215 \\
\hline 8 & Shoots down other people's ideas in public & 22 & 26 & 45 & 15 & 18 & 4 & & \\
\hline & & 16.9 & 20 & 34.6 & 11.5 & 13.8 & 3.1 & 2.95 & 1.354 \\
\hline 9 & Exhibits different behaviours with & 7 & 10 & 6 & 1 & 43 & 63 & & \\
\hline & subordinates than with supervisors & 5.4 & 7.7 & 4.6 & 0.8 & 33.1 & 48.5 & 4.94 & 1.498 \\
\hline 10 & Makes unrealistic time demands on others & 7 & 11 & 7 & 29 & 54 & 22 & & \\
\hline & & 5.4 & 8.5 & 5.4 & 22.3 & 41.5 & 16.9 & .37 & 1.359 \\
\hline 11 & Does not find it necessary to explain his/her & 7 & 11 & 4 & 39 & 47 & 22 & 434 & \\
\hline & decisions to others & 5.4 & 8.5 & 3.1 & 30 & 36.2 & 16.9 & 4.34 & 1.338 \\
\hline 12 & *Willing to listen to others' opinions, ideas, or & 4 & 8 & 15 & 60 & 22 & 21 & 16 & 200 \\
\hline & perspectives & 3.1 & 6.2 & 11.5 & 46.2 & 16.9 & 16.2 & 4.10 & 1.200 \\
\hline 13 & *Welcomes constructive feedback & 4 & 8 & 14 & 49 & 29 & 26 & & 1255 \\
\hline & & 3.1 & 6.2 & 10.8 & 37.7 & 22.3 & 20 & 4.30 & 5 \\
\hline 14 & *Takes responsibility for his/her own mistakes & 6 & 5 & 9 & 30 & 60 & 20 & & \\
\hline & & 4.6 & 3.8 & 6.9 & 23.1 & 46.2 & 15.4 & .48 & .221 \\
\hline 15 & * Never criticizes other employees in a & 11 & 11 & 14 & 56 & 30 & 8 & & 201 \\
\hline & threatening manner & 8.5 & 8.5 & 10.8 & 43.1 & 23.1 & 6.2 & & 291 \\
\hline 16 & * Realizes that it does not always have to be & 3 & 11 & 14 & 69 & 26 & 7 & & \\
\hline & 'his/her way or the highway' & 2.3 & 8.5 & 10.8 & 53.1 & 20 & 5.4 & 3.96 & 1.037 \\
\hline 17 & $*$ Avoids getting angry when his/her ideas are & 4 & 7 & 10 & 72 & 25 & 12 & & \\
\hline & criticized & 3.1 & 5.4 & 7.7 & 55.4 & 19.2 & 9.2 & .10 & 1.063 \\
\hline 18 & $*$ Takes him/herself too seriously & 3 & 9 & 13 & 69 & 30 & 6 & & \\
\hline & & 2.3 & 6.9 & 10 & 53.1 & 23.1 & 4.6 & 4.02 & 004 \\
\hline 19 & * Gives others credit for their ideas & 6 & 9 & 8 & 56 & 37 & 14 & 4.16 & 1206 \\
\hline & & 4.6 & 6.9 & 6.2 & 43.1 & 28.5 & 10.8 & 4.10 & 1.200 \\
\hline 20 & * Is considerate of others' workloads & 3 & 10 & 4 & 45 & 47 & 21 & 4.43 & 1.174 \\
\hline
\end{tabular}




\begin{tabular}{|c|c|c|c|c|c|c|c|c|c|}
\hline & & 2.3 & 7.7 & 3.1 & 34.6 & 36.2 & 16.2 & \multirow[b]{2}{*}{4.32} & \multirow[b]{2}{*}{1.021} \\
\hline 21 & * Is willing to take credit for success as well & $\begin{array}{c}3 \\
23\end{array}$ & $\begin{array}{c}5 \\
38\end{array}$ & $\begin{array}{c}6 \\
46\end{array}$ & $\begin{array}{c}63 \\
485\end{array}$ & $\begin{array}{l}39 \\
30\end{array}$ & 14 & & \\
\hline \multirow[t]{2}{*}{22} & * Does not mind doing menial tasks & 2 & 11 & 5 & 21 & 45 & 46 & \multirow{2}{*}{4.80} & \multirow{2}{*}{1.284} \\
\hline & & 1.5 & 8.5 & 3.8 & 16.2 & 34.6 & 35.4 & & \\
\hline 23 & $\begin{array}{l}\text { y attention without } \\
\text { heated up' }\end{array}$ & $\begin{array}{c}5 \\
3.8\end{array}$ & $\begin{array}{c}8 \\
6.2\end{array}$ & $\begin{array}{c}12 \\
9.2\end{array}$ & $\begin{array}{c}57 \\
43.8\end{array}$ & $\begin{array}{c}42 \\
32.3\end{array}$ & $\begin{array}{c}6 \\
4.6\end{array}$ & 4.08 & 1.093 \\
\hline 24 & $\begin{array}{l}\text { * Promises to address subordinates' } \\
\text { complaints with every intention of working to } \\
\text { resolve them }\end{array}$ & $\begin{array}{c}3 \\
2.3\end{array}$ & $\begin{array}{l}12 \\
9.2\end{array}$ & $\begin{array}{c}5 \\
3.8\end{array}$ & $\begin{array}{c}63 \\
48.5\end{array}$ & $\begin{array}{c}24 \\
18.5\end{array}$ & $\begin{array}{c}23 \\
17.7\end{array}$ & 4.25 & 1.208 \\
\hline 25 & $\begin{array}{l}* \text { Does not see him/herself as being too } \\
\text { important for some tasks }\end{array}$ & $\begin{array}{c}1 \\
0.8\end{array}$ & $\begin{array}{c}8 \\
6.2\end{array}$ & $\begin{array}{c}8 \\
6.2\end{array}$ & $\begin{array}{c}56 \\
43.1\end{array}$ & $\begin{array}{c}46 \\
35.4\end{array}$ & $\begin{array}{l}11 \\
8.5\end{array}$ & 4.32 & .989 \\
\hline 26 & $\begin{array}{l}\text { * Puts organizational objectives before his/her } \\
\text { personal agenda }\end{array}$ & $\begin{array}{c}3 \\
2.3\end{array}$ & $\begin{array}{c}21 \\
16.2\end{array}$ & $\begin{array}{c}16 \\
12.3\end{array}$ & $\begin{array}{c}33 \\
25.4\end{array}$ & $\begin{array}{c}46 \\
35.4\end{array}$ & $\begin{array}{l}11 \\
8.5\end{array}$ & 4.01 & 1.297 \\
\hline
\end{tabular}

* = Reverse coded statements, $\mathrm{SD}=$ Standard deviation

Appendix B - Descriptive statistics of normative commitment

Descriptive statistics of normative commitment $(\mathrm{N}=130)$

\begin{tabular}{|c|c|c|c|c|c|c|c|c|c|}
\hline & \multirow{2}{*}{ Items } & \multicolumn{6}{|c|}{ Likert Scale } & \multirow{2}{*}{ Mean } & \multirow{2}{*}{ SD } \\
\hline & & 1 & 2 & 3 & 4 & 5 & 6 & & \\
\hline \multirow[t]{2}{*}{1} & I think that people these days move from & 1 & 10 & 15 & 46 & 54 & 4 & \multirow[t]{2}{*}{4.18} & \multirow{2}{*}{1.002} \\
\hline & company to company to & 0.8 & 7.7 & 11.5 & 35.4 & 41.5 & 3.1 & & \\
\hline \multirow[t]{2}{*}{2} & *I do not believe that a person must always be & 4 & 61 & 49 & 6 & 6 & 4 & \multirow{2}{*}{2.70} & \multirow{2}{*}{1.009} \\
\hline & loyal to his or her organ & 3.1 & 46.9 & 37.7 & 4.6 & 4.6 & 3.1 & & \\
\hline \multirow[t]{2}{*}{3} & *Jumping from organisat & 7 & 34 & 78 & 5 & 4 & 2 & \multirow[t]{2}{*}{2.78} & .856 \\
\hline & $\begin{array}{l}\text { does not seem at all unethical to me. } \\
\text { One of the major reasons I continue to work in }\end{array}$ & 5 & .2 & 60 & .8 & 1 & & & \multirow{3}{*}{1.001} \\
\hline \multirow{2}{*}{4} & & 6 & 9 & 24 & $\begin{array}{c}73 \\
562\end{array}$ & 15 & 3 & \multirow[t]{2}{*}{3.70} & \\
\hline & obliga & & & 10.5 & & 11.5 & 2.3 & & \\
\hline \multirow[t]{2}{*}{5} & If I got another offer for a better job elsewhere I & 13 & 73 & 21 & 12 & 9 & 2 & \multirow{2}{*}{2.52} & \multirow{2}{*}{1.115} \\
\hline & $\begin{array}{l}\text { Would } \\
\text { organis }\end{array}$ & 10 & 56.2 & 16.2 & 9.2 & 6.9 & 1.5 & & \\
\hline \multirow[t]{2}{*}{6} & I was taught to believe in the value of remaining & 2 & 13 & 45 & 60 & 9 & 1 & \multirow{2}{*}{3.49} & \multirow[t]{2}{*}{.856} \\
\hline & $\begin{array}{l}\text { loyal to one organisation. } \\
\text { Things were better in the days when people }\end{array}$ & 1.5 & 10 & 34.6 & 46.2 & 6.9 & 0.8 & & \\
\hline 7 & $\begin{array}{l}\text { stayed in one organisation for most of their } \\
\text { careers. }\end{array}$ & $\begin{array}{c}8 \\
6.2\end{array}$ & $\begin{array}{c}15 \\
11.5\end{array}$ & $\begin{array}{c}83 \\
63.8\end{array}$ & $\begin{array}{c}15 \\
11.5\end{array}$ & $\begin{array}{c}6 \\
4.6\end{array}$ & $\begin{array}{c}3 \\
2.3\end{array}$ & 3.04 & .935 \\
\hline 8 & $\begin{array}{l}\text { *I do not think that to be a 'company man' or } \\
\text { 'company woman' is sensible anymore. }\end{array}$ & $\begin{array}{l}11 \\
8.5\end{array}$ & $\begin{array}{c}58 \\
44.6\end{array}$ & $\begin{array}{c}49 \\
37.7\end{array}$ & $\begin{array}{c}7 \\
5.4\end{array}$ & $\begin{array}{c}3 \\
2.3\end{array}$ & $\begin{array}{c}2 \\
1.5\end{array}$ & 2.53 & .925 \\
\hline
\end{tabular}

Note:

$*=$ Reverse coded statements, $\mathrm{SD}=$ Standard deviation

Appendix C - Descriptive statistics of affective commitment

Descriptive statistics of affective commitment $(\mathrm{N}=130)$

\begin{tabular}{|c|c|c|c|c|c|c|c|c|c|}
\hline & \multirow[b]{2}{*}{ Items } & \multicolumn{6}{|c|}{ Likert Scale } & \multirow{2}{*}{ Mean } & \multirow{2}{*}{ SD } \\
\hline & & 1 & 2 & 3 & 4 & 5 & 6 & & \\
\hline \multirow[t]{2}{*}{1} & I would be very happy to spend the rest of my career & 28 & 52 & 33 & 9 & 6 & 2 & \multirow{2}{*}{2.38} & \multirow{2}{*}{1.129} \\
\hline & with this organisation. & 21.5 & 40 & 25.4 & 6.9 & 4.6 & 1.5 & & \\
\hline \multirow[t]{2}{*}{2} & I enjoy discussing about my & 7 & 50 & 48 & 12 & 11 & 2 & \multirow{2}{*}{2.82} & \multirow{2}{*}{1.070} \\
\hline & outsic & 5.4 & 38.5 & 36.9 & 9.2 & 8.5 & 1.5 & & \\
\hline \multirow[t]{2}{*}{3} & I really feel as if this organisation's problems are my & 5 & 60 & 51 & 9 & 4 & 1 & \multirow{2}{*}{2.62} & \multirow{2}{*}{.857} \\
\hline & own & 3.8 & 46.2 & 39.2 & 6.9 & 3.1 & 0.8 & & \\
\hline 4 & *I think that I could easily become as attached to another & 3 & 15 & $\begin{array}{c}66 \\
508\end{array}$ & 37 & 8 & 1 & 3.27 & .861 \\
\hline \multirow[t]{2}{*}{5} & *I do not feel like 'part of the family' at my organisation. & $\begin{array}{c}2.5 \\
4\end{array}$ & 26 & $\begin{array}{l}50.0 \\
79\end{array}$ & $\begin{array}{c}20.5 \\
15\end{array}$ & 5 & 1 & \multirow{2}{*}{2.95} & \multirow{2}{*}{.815} \\
\hline & & 3.1 & 20 & 60.8 & 11.5 & 3.8 & 0.8 & & \\
\hline \multirow[t]{2}{*}{6} & *I do not feel 'emotionally attached' to this organisation. & 6 & 32 & 71 & 14 & 7 & 0 & \multirow{2}{*}{2.88} & \multirow{2}{*}{.863} \\
\hline & & 4.6 & 24.6 & 54.6 & 10.8 & 5.4 & 0 & & \\
\hline 7 & This organisation has a great deal of personal meaning & 1 & 28 & 68 & 22 & 10 & 1 & 3.12 & .886 \\
\hline
\end{tabular}




\begin{tabular}{llcccccccc}
\hline & for me. & 0.8 & 21.5 & 52.3 & 16.9 & 7.7 & 0.8 & \\
8 & $*$ I do not feel a 'strong' sense of belonging to my & 8 & 37 & 63 & 15 & 6 & 1 & 2.82 & .936 \\
\hline & organisation. & 6.2 & 28.5 & 48.5 & 11.5 & 4.6 & 0.8 & \\
\hline
\end{tabular}

Note:

$*=$ Reverse coded statements, $\mathrm{SD}=$ Standard deviation

Appendix D - Descriptive statistics of continuance commitment

Descriptive statistics of continuance commitment $(\mathrm{N}=130)$

\begin{tabular}{|c|c|c|c|c|c|c|c|c|c|}
\hline & \multirow{2}{*}{ Items } & \multicolumn{6}{|c|}{ Likert Scale } & \multirow{2}{*}{ Mean } & \multirow{2}{*}{ SD } \\
\hline & & 1 & 2 & 3 & 4 & 5 & 6 & & \\
\hline \multirow[t]{2}{*}{1} & *I am not afraid of what might happen if I quit & 2 & 12 & 7 & 37 & 53 & 19 & \multirow{2}{*}{4.42} & \multirow{2}{*}{1.180} \\
\hline & my job without having another one lined up. & 1.5 & 9.2 & 5.4 & 28.5 & 40.8 & 14.6 & & \\
\hline \multirow[t]{2}{*}{2} & It would be very hard for me to leave my & 4 & 12 & 11 & 80 & 21 & 2 & \multirow{2}{*}{3.83} & \multirow{2}{*}{.966} \\
\hline & organisation right now, even if I wanted to. & 3.1 & 9.2 & 8.5 & 61.5 & 16.2 & 1.5 & & \\
\hline \multirow[t]{2}{*}{3} & Too much in my life would be disrupted if I & 2 & 7 & 12 & 86 & 19 & 4 & \multirow{2}{*}{3.96} & \multirow{2}{*}{.848} \\
\hline & decided to leave my organisation now. & 1.5 & 5.4 & 9.2 & 66.2 & 14.6 & 3.1 & & \\
\hline \multirow[t]{2}{*}{4} & *It wouldn't be too costly for me to leave my & 3 & 4 & 13 & 53 & 51 & 6 & \multirow{2}{*}{4.25} & \multirow{2}{*}{.975} \\
\hline & organisation now. & 2.3 & 3.1 & 10 & 40.8 & 39.2 & 4.6 & & \\
\hline \multirow[t]{2}{*}{5} & Right now, staying with my organisation is a & 2 & 6 & 5 & 45 & 51 & 21 & \multirow{2}{*}{4.54} & \multirow{2}{*}{1.058} \\
\hline & matter of necessity as much as desire. & 1.5 & 4.6 & 3.8 & 34.6 & 39.2 & 16.2 & & \\
\hline \multirow[t]{2}{*}{6} & I feel that I have very few options to consider & 3 & 8 & 4 & 33 & 55 & 27 & \multirow{2}{*}{4.62} & \multirow{2}{*}{1.171} \\
\hline & leaving this organisation. & 2.3 & 6.2 & 3.1 & 25.4 & 42.3 & 20.8 & & \\
\hline \multirow[t]{2}{*}{7} & One of the few serious consequences of leaving & 2 & 9 & 6 & 28 & 47 & 38 & \multirow{2}{*}{4.72} & \multirow{2}{*}{1.221} \\
\hline & available alternatives. & 1.5 & 6.9 & 4.6 & 21.5 & 36.2 & 29.2 & & \\
\hline \multirow[t]{3}{*}{8} & $\begin{array}{l}\text { One of the major reasons I continue to work for } \\
\text { this organisation is that leaving would require }\end{array}$ & & & & & & & \multirow{3}{*}{4.49} & \multirow{3}{*}{1.073} \\
\hline & considerable personal sacrifice - another & 2 & $\begin{array}{c}9 \\
69\end{array}$ & 2 & 44 & 56 & 17 & & \\
\hline & $\begin{array}{l}\text { organisation may not match the overall benefits I } \\
\text { have here. }\end{array}$ & & 0.9 & & & $4 J .1$ & 15.1 & & \\
\hline
\end{tabular}

Note:

$*=$ Reverse coded statements, $\mathrm{SD}=$ Standard deviation

\section{References}

Allen, N. J., \& Meyer, J. P. (1990a). Organizational socialization tactics: A longitudinal analysis of links to newcomers' commitment and role orientation. The Academy of Management Journal, 33(4), 847-858. doi: $10.2307 / 256294$

Allen, N. J., \& Meyer, J. P. (1990b). The measurement and antecedents of affective, continuance and normative commitment to the organization. Journal of Occupational Psychology, 63(1), 1-18. doi:10.1111/j.20448325.1990.tb00506.x

Allen, N. J., \& Meyer, J. P. (1993). Organizational commitment: Evidence of career stage effects? Journal of Business Research, 26(1), 49-61. doi:10.1016/01482963(93)90042-N

Bolboaca, S. D., \& Jäntschi, L. (2006). Pearson versus Spearman, Kendall's tau correlation analysis on structureactivity relationships of biologic active compounds. Leonardo Journal of Sciences, 5(9), 179-200

Borden, L. A. (2017). Bosses and Burnout: The Interpersonal Consequences of Leader Arrogance for Subordinates (Unpublished doctoral dissertation). University of Akron

Cansoy, R. (2019). The relationship between school principals' leadership behaviours and teachers' job satisfaction: A Systematic Review. International Education Studies, 12(1), 37-52

Chang, L. (1994). A psychometric evaluation of 4-point and 6-point Likert-type scales in relation to reliability and validity. Applied psychological measurement, 18(3), 205-215

Chomeya, R. (2010). Quality of psychology test between Likert scale 5 and 6 points. Journal of Social Sciences, 6(3), $399-403$ 
Coakes, S. J., \& Steed, L. (2009). SPSS: Analysis without anguish using SPSS version 14.0 for Windows. John Wiley \& Sons, Inc

Deal, T. E. (1985). The symbolism of effective schools. Elementary School Journal, 85(5), 601-620

De Vaus, D. A. (2001). Research design in social research. Sage

Dykes, A. C., \& Winn, G. L. (2019). Identifying toxic leadership and building worker resilience. Professional Safety, 64(3), 38-45

Fraenkel, J. R., Wallen, N. E., \& Hyun, H. H. (2011). How to design and evaluate research in education. New York: McGraw-Hill Humanities/Social Sciences/Languages

Granello, D. H., \& Wheaton, J. E. (2004). Online data collection: Strategies for research. Journal of Counseling \& Development, 82(4), 387-393

Green, S. B., \& Salkind, N. J. (2007). Using SPSS for Windows and Macintosh: Analyzing and understanding data (5th ed.). Upper Saddle River, NJ: Pearson/Prentice Hall

Haan, P., Britt, M. M., \& Weinstein, A. (2007). Business students' perceptions of arrogance in academia. College Student Journal, 41(1), 82-93

Hair, J. F., Black, W. C., Babin, B. J., Anderson, R. E., \& Tatham, R. L. (1998). Multivariate data analysis (Vol. 5, No. 3, pp. 207-219). Upper Saddle River, NJ: Prentice hall

Hamedoğlu, M. A. (2019). Perceptions of Principals and Teachers on the Level of Organizational Narcissism, High Schools in Sakarya Province Sample. Sakarya University Journal of Education, 9(1), 148-170

Hazriyanto, H., \& Ibrahim, B. (2019). The factor analysis of organizational commitment, job satisfaction, and performance among lecturers in Batam. Journal of Technical Education and Training, 11(1). 151-158

Jaros, S. (2007). Meyer and Allen model of organizational commitment: Measurement issues. The Icfai Journal of Organizational Behavior, 6(4), 7-25

Johnson, R. E., Silverman, S. B., Shyamsunder, A., Swee, H., Rodopman, O. B., Cho, E., \& Bauer, J. (2010). Acting superior but actually inferior?: Correlates and consequences of workplace arrogance. Human Performance, 23(5), 403427. doi:10.1080/08959285.2010.515279

Kemper, E. A., Stringfield, S., \& Teddlie, C. (2003). Mixed methods sampling strategies in social science research. Handbook of Mixed Methods in Social and Behavioral Research, 273-296

Liborius, P. (2017). What does leaders' character add to transformational leadership? The Journal of Psychology, 151(3), 299-320. doi:10.1080/00223980.2016.1270889

Lohr, S. L. (2019). Sampling: Design and Analysis: Design and Analysis. Chapman and Hall/CRC

Mendoza, E. C. (2019). The mediating role of job involvement between job satisfaction and organizational commitment in a small and medium sized business enterprise. International Review of Management and Marketing, 9(5), 74-81. doi:10.32479/irmm.8355

Meyer, J. P., Paunonen, S. V., Gellatly, I. R., Goffin, R. D., \& Jackson, D. N. (1989). Organizational commitment and job performance: It's the nature of the commitment that counts. Journal of Applied Psychology, 74(1), $152-156$. doi:10.1037/0021-9010.74.1.152

Minnaar, L., \& Heystek, J. (2013). Online surveys as data collection instruments in education research: A feasible option?. South African Journal of Higher Education, 27(1), 162-183

Neuman, W. L. (2011). Social research methods: Qualitative and quantitative Approaches (7th ed.). Boston: Allyn \& Bacon

Nulty, D. D. (2008). The adequacy of response rates to online and paper surveys: What can be done? Assessment \& Evaluation in Higher Education, 33(3), 301-314. doi:10.1080/02602930701293231 
Oyer, B. J. (2015). Teacher perceptions of principals' confidence, humility, and effectiveness: Implications for educational leadership. Journal of School Leadership, 25(4), 684-719. doi:10.1177/105268461502500405

Ozdem, G., \& Sezer, S. (2019). The relationship between solution-focused school leadership and organizational cynicism, organizational commitment and teachers' job satisfaction. International Journal of Progressive Education, 15(1). 167-183

Parker, B. A. L. (2015). A Synthesis of Theory and Research on Principal Leadership, School Culture, and School Effectiveness (Doctoral dissertation). Retrieved from http://vtechworks.lib.vt.edu

Saba, I. (2011). Measuring the job satisfaction level of the academic staff in Bahawalpur colleges. International Journal of Academic Research in Business and Social Sciences, 1(1), 1-8

Senarai Daftar IPTS. (2019, November 30). Jabatan Pendidikan Tinggi, Kementerian Pendidikan Malaysia. Retrieved from http://jpt.mohe.gov.my/portal/ipts/institusi-pendidikan-tinggi-swasta/senarai-daftar-dan-statistik-ipts

Sekaran, U., \& Bougie, R. (2010). Theoretical framework in theoretical framework and hypothesis development. Research Methods for Business: A Skill Building Approach, 80. 13-25

Sharma, G. D., Aryan, R., Singh, S., \& Kaur, T. (2019). A systematic review of literature about leadership and organization. Research Journal of Business Management, 13, 1-14

Sheehan, K. B. (2001). E-mail survey response rates: A review. Journal of Computer Mediated Communication, 6(2), Retrieved from https://doi.org/10.1111/j.1083-6101.2001.tb00117.x

Silverman, S. B., Johnson, R. E., McConnell, N., \& Carr, A. (2012). Arrogance: A formula for leadership failure. The Industrial-Organizational Psychologist, 50(1), 21-28

Tatlah, I. A., Akhtar, S. N., \& Hashmi, M. A. (2019). Effect of instructional leadership on teachers' performance and job commitment: A comparison of public and private universities of lahore. Journal of Educational Research, 22(1), $133-144$

Torlak, N. G., \& Kuzey, C. (2019). Leadership, job satisfaction and performance links in private education institutes of Pakistan. International Journal of Productivity and Performance Management, 68(2), 276-295

Toscano, R., Price, G., \& Scheepers, C. (2018). The impact of CEO arrogance on top management team attitudes. European Business Review, 30(6), 630-644. doi:10.1108/EBR-12-2016-0156

Trimmer, K., Dixon, R., \& Guenther, J. (2019). School leadership and Aboriginal student outcomes: systematic review. Asia-Pacific Journal of Teacher Education, 1-17. doi: https://doi.org/10.1007/978-3-319-77751-1_12

Trumpeter, N., Watson, P. J., \& O’Leary, B. J. (2006). Factors within multidimensional perfectionism scales: Complexity of relationships with self-esteem, narcissism, self-control, and self-criticism. Personality and Individual Differences, 41(5), 849-860. doi:10.1016/j.paid.2006.03.014

Uysal, H. T. (2019). The Mediation Role of Toxic Leadership in the Effect of Job Stress on Job Satisfaction. International Journal of Business, 24(1).55-73

van den Berg, Peter T, \& Wilderom, C. P. M. (2004). Defining, measuring, and comparing organisational cultures. Applied Psychology an International Review, 53(4), 570-582. doi:10.1111/j.1464-0597.2004.00189.x

Weiss, D. J., Dawis, R. V., \& England, G. W. (1967). Manual for the Minnesota satisfaction questionnaire. Minnesota studies in vocational rehabilitation 